\title{
Engelli Çocuğa Sahip Ebeveynlerde Bakım Veren Yükü ve Depresyon Durumlarının İncelenmesi
}

\section{Examination of Caregiver Burden and Depression Conditions of Parents with Disabled Children}

\author{
Besey Ören ${ }^{1}$ Reyhan Aydın²* \\ ${ }^{1}$ Sağlık Bilimleri Üniversitesi, Sağlık Bilimleri Fakültesi, Ebelik Bölümü, Karabük Üniversitesi, Türkiye \\ ${ }^{2}$ Sağlık Bilimleri Üniversitesi, Sağlık Bilimleri Fakültesi, Ebelik Anabilim Dalı Doktora Öğrencisi, Karabük \\ Üniversitesi, Türkiye \\ e-mail: besey_oren@yahoo.com,reyhan.aydin_@hotmail.com \\ ORCID: 0000-0003-4182-7226 \\ ORCID: 0000-0003-4950-3699 \\ *Sorumlu yazar/ Corresponding Author: Öğr. Gör. Reyhan AYDIN* \\ Gönderim Tarihi / Received: 30.01 .2020 \\ Kabul Tarihi / Accepted: 07.05.2020 \\ DOI: $10.34087 /$ cbusbed.682392
}

\section{Öz}

Giriş ve Amaç: Çalışma engelli çocuğa sahip ebeveynlerin bakım veren yükü ve depresyon durumlarını belirlemek amaciyla planlandi.

Gereç ve Yöntemler: Kesitsel ve tanımlayıcı olarak yapılan araştırmanın örneklemini 15 Haziran - 15 Ağustos 2018 tarihleri arasında çocuklarını özel eğitim merkezine getiren, okuma-yazma bilen ve araştırmaya katılmayı kabul eden 100 ebeveyn oluşturdu. Veri toplama aracı olarak, araştırmacılar tarafından literatür doğrultusunda hazırlanan 16 sorudan oluşan Sosyo-demografik özellikleri içeren veri toplama formu, Bakım Verme Yükü Ölçeği ve Beck Depresyon Envanteri kullanıldı. Ebeveynlerden yazılı izin ve Karabük Üniversitesi Girişimsel Klinik Araştırmalar Etik kurulundan onay alınd1.

Bulgular: Bakım veren ebeveynlerin \%78'inin anne, \%22'sinin baba olduğu, bakım verilen çocukların \%63'ünün k1z, \%37'sinin erkek olduğu saptandı. Engelli çocukların \%35'inin 0-6 yaş, \%31'inin 7-12 yaş ve \%34'ünün 13-18 yaş aralığında olduğu, engelli çocukların; \%17'sinin fiziksel, \%59'unun zihinsel , \%24'ününde genetik bir hastalığa bağlı engele sahip olduğu görüldü. Anne ve babaların bakım yükü puanları arasında anlamlı bir fark olmadığı ancak depresyon durumları arasında istatistiksel olarak anlamlı bir ilişki olduğu görüldü. Bakım veren babaların depresyon puanın annelerden daha yüksek olduğu saptandı. Ebeveynlerin hem bakım yükü hem de depresyon puanlarının ilk okul mezunu olanlarda daha yüksek olduğu saptandı. Ebeveynlerin bakım yükü ve depresyon puanları arasında da pozitif yönde bir ilişki olduğu, bakım veren yükü arttıkça depresyon olanlarda orantılı olarak arttığı saptandı.

Sonuç: Engelli bir çocuğa sahip olmanın bakım yükü bakımından anne veya baba açısından farklı olmadığı, ebeveyn eğitiminin bakım yükünde etkili olduğu ve böyle bir çocuğa bakım vermenin depresyon-anksiyete yaşanmasında önemli bir etken olduğu, babaların annelere oranla daha fazla depresyon yaşadığı sonucuna varıldı.

Anahtar kelimeler: Engelli çocuk, bakım yükü, depresyon.

\footnotetext{
Abstract

Objective: The study was planned to determine the caregiver burden and depression states of parents with children with disabilities.

Materials and Methods: The sample of the cross-sectional and descriptive study consisted of 100 parents who brought their children to the special education center between 15 June and 15 August 2018, who knew how to read and write and agreed to participate in the research. As the data collection tool, data collection form including Sociodemographic features consisting of 16 questions prepared by the researchers in line with the literature, Maintenance Payload Scale and Beck Depression Inventory were used. Written permission from parents and approval from the Ethical Committee of Interventional Clinical Researches of Karabuk University was obtained.
} 
Results: It was determined that $78 \%$ of the caregiving parents were mothers, $22 \%$ were fathers, $63 \%$ of the children who were cared for were girls and $37 \%$ were boys. Children with disabilities are in the range of 0-6 years old, 35\% 712 years old and 34\% 13-18 years old. It was observed that 17\% had physical, 59\% mental, and 24\% genetic disease. It was observed that there was no significant difference between the care burden scores of the mothers and fathers but there was a statistically significant relationship between the depression states $(p=0.016)$. It was determined that the depression score of the caregivers was higher than the mothers. It was found that both parents' burden of care and depression were higher in primary school graduates. It was determined that there was a positive relationship between the care burden and depression scores of the parents, and the depression score increased proportionally as the caregiver burden increased.

Conclusion: It was concluded that having a disabled child is not different in terms of care burden for the mother or father, parental education is effective on the care burden and that caring for such a child is an important factor in experiencing depression-anxiety, and fathers experience more depression than mothers

Keywords: Disabled child, care burden, depression.

\section{Giriş}

Engellilik hangi grupta veya hangi konuda olursa olsun bireyi, aileyi ve toplumu ilgilendiren önemli bir sorunudur. Engelli çocuk, etrafindaki uyaranları algılama, değerlendirme, öğrenme, düşünme, bilgileri kavramlaştırma, öğrendikleriyle deneyimledikleri arasında bağlantı yeteneklerini kullanamayan, kendi iç dünyasında yaşamaya çalışan veya herhangi bir fiziksel ve motor yetersizliği olan çocuk olarak tanımlanmaktadır [1-4]. Diğer bir ifade ile; fiziksel, zihinsel, sosyal ve tıbbi açıdan kendi yaş grubundan geride kalan çocuklar 'engelli çocuk' olarak tanımlanmaktadır [4].

Dünya nüfusunun \%15'i yani yaklaşı olarak 1000 milyondan fazla kişinin engelli olduğu bilinmektedir [5]. Bu her 7 kişiden 1 kişinin engelli olduğu anlamına gelir. $\mathrm{Bu}$ popülasyonun yaklaşık 93 milyondan fazlasının 15 yaş altı çocuk olduğu tahmin edilmektedir. Her geçen gün kronik hastalıkların artması, ülkelerdeki sağlık sorunlarının artışı ya da çevresel ve diğer faktörlerden kaynaklı olarak engelli oranı da artmaktadır [5]. Ülkemizde engelli çocuk oranının 5,5-6 milyonun üzerinde olduğu tahmin edilmektedir. Çocuklardaki engel durumu zihinsel, fiziksel ya da sosyal engeli kapsamaktadır [6].

Engelli çocuk olduğunda sadece engelli birey değil aynı zamanda çocuğa bakmakla yükümlü olan aile bireyleri de ciddi şekilde etkilemektedir. Aile bireylerini bu bakım sürecinin içine kattığımızda ise, engelli çocuğun yaşadığı sorun ve sıkıntıların 20 milyondan fazla kiși ile ilgili olduğunu söylenebilir [7]. Çocuğunda engel olan aile bireyleri olumsuz yönde etkilemekte ve bu durum aile için oldukça ciddi travmatik bir süreç haline gelmektedir. Bu süreç aileler üzerinde hem psikolojik hem de fiziksel bir yük oluşturmaktadır. Çocuğun bakımının fiziksel ve ruhsal anlamda güçlüğü aile arasında etkileşimi de etkilemektedir [7-9].

Bakım verme; bakım veren ebeveyn tarafından birçok yönden olumlu ya da olumsuz olarak algilanan bir süreçtir. $\mathrm{Bu}$ süreç sevgi ile desteklenen büyük oranda samimiyetin artmasına da neden olan, yakın ilişkilerin gelişmesine, diğer kişilerden sosyal destek alma, kişisel doyum alma gibi birçok olumlu duyguyu yaşatıyor olmasına rağmen, duygusal stres, kişilerarası ilişkilerde azalma, aile içi ilişkilerde bozulma, maddi güçlük ve meslek hayatının olumsuz etkilenmesi gibi bakım veren ebeveyni birçok güçlükle de karşı karşıya getirmektedir [8-10].

Çocuğun dünyaya gelmesi aile için büyük bir neşe kaynağ 1 olarak karşılanmakla birlikte, engelli bir çocuğa sahip olmak beraberinde ailenin yaşayacağı birçok güçlüğü de beraberinde getirmektedir [11]. Engelli bir çocuğun anne- babası olmak ya da engelli bir kardeşe sahip olmak aile içinde bir yük olarak düşünülmektedir. Eğitim durumu, maddi zorluk, psikolojik durum, yaşam tarzı değişiklikleri ve çevresi ile etkileşimde yaşanılacak olan yük ya da zorluklar aile içi işlevi önemli derecede etkiler [12]. Çiftlerin bu süreçte çocuklarının günlük yaşamını organize etmek gibi birçok sıkıntıyla karşı karşıya kaldıkları ve bu sürecin iyi idare edilmesinde en büyük yükün anneye kaldığ 1 görülmektedir [13]. Birçok çalışma engelli çocuğun aile üzerinde oluşturduğu ekstra stres nedeni ile; aile içi iletişimin ve ailenin maddi durumunun etkilemesinin yanı sıra, ebeveynlerin kayg1 düzeyini arttırarak anne baba arasındaki uyumda azalmaya ve kişisel ilişkileri arasında bozulmaya neden olduğunu bildirmektedir [11-13].

Ebeveynlerin çocuğunu yetiştirme, eğitme ve yaşamında birçok sorumluluğu paylaşması gerekir. Ancak ebeveynler bunu yaparken özellikle çocukları engelli ise rol ve işlevlerinde karıșıklık yaşayabilirler. Anne ve babanın bu konuya bakış açısı ve aile arasındaki işlevlerini nasıl değerlendirdikleri çocuklarının bakım, eğitim ve gelişim süreci üzerinde önemli etkiye sahiptir [11-13].

Bakım veren ebeveynlerin bakım verme yükünü paylaşmaları ve sağlıklı bir şekilde yürütmeleri, çocuklarının bakım ve gelişim süreci üzerinde olumlu yönde katkıda bulunacağı öngörülmektedir. Ancak bunun için öncelikle engelli çocuğa bakım verenlerin yükünün ve ebeveynleri nasıl etkilediğinin bilinmesi önemlidir. Bu çalışma engelli çocuğa sahip ebeveynlerin bakım veren yükü ve depresyon durumlarını belirlemek amacıyla planlanmıştır.

\section{Materyal and Metot}

\section{Araştırmanın Tipi ve Örneklemi}

Tanımlayıcı ve kesitsel olarak planlanan araştırma, engelli çocuğa sahip olan ebeveynlerin bakım verme yükü ve depresyon durumlarının incelemek amacı ile yapıldı. Çalışmanın evrenini Karabük ili sınırları içinde 
bulunan, özel bir eğitim ve rehabilitasyon merkezine kayıtlı olan, bedensel, zihinsel ya da her iki engele sahip çocukların ebeveynleri (n: 220) oluşturdu. Örneklemini ise 15 Haziran - 15 Ağustos 2018 tarihleri arasında çocuklarını özel eğitim merkezine getiren, okuma-yazma bilen ve araştırmaya katılmayı kabul eden 100 ebeveyn oluşturdu.

Veri Toplama Araçları

Araştırma verileri, araştırmacılar tarafından literatür doğrultusunda hazırlanan 16 sorudan oluşan sosyodemografik özellikleri içeren Veri Toplama Formu, Bakım Verme Yükü Ölçeği ve Beck Depresyon Envanteri kullanılarak topladı. Karabük Üniversitesi Girişimsel Olmayan Klinik Araştırmalar Etik Kurulu'ndan (18.06.2018 tarihli ve 77192459-050.99E.5201 6/17 sayılı) izin ve araştırmanın yapılacağ kurumdan kurum izinleri alındı ve çalışmaya katılmayı kabul eden ebeveynlere araştırmanın amacı ve gönüllü olur formu doldurulduktan sonra veriler yüz yüze görüşme yöntemi ile topland.

Bakım Verme Yükü Ölçeği

Geçerlilik çalışması İnci ve ark. (2008) tarafından yapılan Bakım Verme Yükü Ölçeği [14]. 22 sorudan oluşmaktadır ve "asla", "nadiren”, "bazen”, "sık sık" ya da "hemen her zaman" şeklinde " 1 " den " 5 " e kadar değişen Likert tipi bir ölçektir. Ölçekten en az 22, en fazla 110 puan alınabilmektedir. Ölçeğin kesme noktasına ilişkin bir veri bulunmamakla birlikte elde edilen puanlar 22-46 arasında ise hafif, 47-55 arasında ise orta, 56 ve üzerinde ise şiddetli düzeyde yük oluşturduğu şeklinde yorumlanmaktadır. Ölçekte yer alan maddeler genellikle sosyal ve duygusal alana yönelik olup, ölçek puanının yüksek olması, bakım veren yükünün de yüksek olduğunu göstermektedir $[14,15]$.

Beck Depresyon Envanteri (BDÖ)

Beck ve ark. tarafından geliştirilmiş olup ülkemizde geçerlilik ve güvenilirlik çalışması, Ulusoy ve arkadaşları tarafindan 1988 yılında yapılmıştır (16). Ölçek yirmi bir belirti kategorisini içeren bir "kendini değerlendirme" ölçeğidir. Alınacak en yüksek puan 63 'tür. Toplam puanın yüksekliği depresyonun şiddetini gösterir (17). Ölçekten alınan 0-9 puan, minimal düzeyde; 10-16 puan, hafif düzeyde; 17-29 puan, orta düzeyde ve 30-63 puan, şiddetli düzeyde depresif belirtiler olarak yorumlanmaktadır. BDÖ’den 17 puan ve üstü alan bir kişide psikiyatrik muayene ile depresyon saptanma olasılığ 1 ortalama \%80, depresyonu olan bir bireyin 16 ve altında puan alma olasılığ ise ortalama $\% 30$ olarak belirlenmiştir [16].

Verilerin Değerlendirilmesi

Araştırmanın istatistiksel analizi bilgisayar destekli istatistik programı kullanılarak değerlendirildi. Verilerin normallik dağılımı Kolmogorov-Smirnov ile değerlendirildi ve paremetrelerin normal dağ 11 lım göstermediği görüldü. Araştırmadan elde edilen veriler, yüzdelik ve frekans dağılımları yapılarak incelendi. Bağımlı ve bağımsız değişkenler arasındaki kıyaslamalar veriler nonparametrik dağılım gösterdiğinden, iki değişkenli gruplarda Mann Whitney U ve üç ve üzeri değişkenli gruplarda da Kruskal Wallis testleri kullanılarak yapıldı. Bakım yükü ve depresyon durumları arasındaki ilişki durumunu incelemek için ise nonparametrik kolerasyon analizi olan Spearman kolerasyon analizi kullanıldı [17]. Elde edilen veriler $\% 95$ güven aralığında ve anlamlılık $\mathrm{p}<0,05$ düzeyinde değerlendirildi.

\section{Bulgular}

Bakım Verme Yükü Ölçeği'nin Türkçe formunun Cronbach Alfası 0,94 [14] ve Beck Depresyon Ölçeğinin Türkçe formunun Cronbach Beck Alfası da 0,93 [18], olarak bulunmuştur. Çalışmamızda ise Bakım Verme Yükü Ölçeği'nin Cronbach alfası 0,85, Beck Depresyon Ölçeğinin Cronbach Alfası da 0,84, olarak bulunmuştur. Bakım veren ebeveynlerin \%78'inin anne, \%22'sinin baba olduğu, \%85'inin evli, olduğu, \%57'sini yaşlarının 26-39 yaş, \%64'ünün ilkokul, \%36'sının lise mezunu olduğu, \% 74'ünün çalışmadığı, bakım verilen çocukların \%63'ünün k1z çocuğu olduğu saptand1. Engelli çocukların \%35'inin 0-6 yaş, \%34'ünün de 13-18 yaş, \%31'inin 7-12 yaş aralığında olduğu, \%17'sinin fiziksel bir engele, \%59'unun zihinsel bir engele ve \%24'ününde genetik bir hastalığa bağlı engele sahip olduğu belirlendi. Çocukların \%73'ünün hafif bir engele (yürüyebildiği ve yemek yeme gibi kendi fiziksel ihtiyaçlarını yapabildiği), $\% 27$ 'sinin orta ve şiddetli bir engele (desteksiz yürüyemediği ve yemek gibi ihtiyaçlarını karşılayamadığı) sahip olduğu saptandı. Çocuklarının \%69'unun doğuştan, \%25'inin 0-1 yaşında ve \%6'sınında 2 yaşında engele sahip olduğu görüldü (Tablo 1)

Tablo 2 incelendiğinde ailelerin \%14'ünün ciddi, $\% 22$ 'sinin orta ciddi, \%48'inin hafif ve \%16'sının da çok az bakım yüküne sahip oldukları görüldü. Ayrıca, \%5'inin minimal, \%30'unun hafif, \%17'sinin orta ve \%48'inin ağır depresyon belirtileri gösterdiği saptand1. Bakım yükü puanlarına göre ebeveynler \%22 oranla orta ciddi ve $\% 48$ oranla hafif bakım yüküne sahipken, Beck depresyon puanlarına göre ise ebeveynlerin \%48'inin ağır depresyon belirtileri gösterdiği tespit edildi. (Tablo 2).

Ebeveynlerin yaşları ile bakım yükü $(\mathrm{p}=0,001)$ puanları arasında istatistiksel olarak anlamlı derecede fark görülmesine rağmen depresyon $(\mathrm{p}=0,063)$ durumları arasında anlamlı bir fark saptanmamıştır.

Çalışmada, ebeveynlerin cinsiyetleri ile bakım yükü puanları arasında istatistiksel olarak anlamlı bir fark olmadığ ${ }_{1}(p=0,55)$, fakat buna karşın depresyon puanları arasında istatistiksel olarak anlamlı derecede $(p=0,16)$ farklılık olduğu görülmüştür. Bakım veren babaların annelerden daha fazla depresyon puanına sahip olduğu saptanmıştır. Ebeveynlerin medeni durumlarına bakıldığında hem bakım yükü $(p=0,375)$ hem de depresyon $(p=0,402)$ puanları arasında istatistiksel olarak anlamlı bir fark bulunmamıştır. Ailelerin eğitim durumları ile bakım yükü $(p=0,002)$ ve depresyon puanları $(\mathrm{p}=0,000)$ arasında istatistiksel olarak anlamlı derece farklılık görülmüştür. Eğitim durumu azaldıkça bakım yükünün ve depresyonun arttığ1 görülmüştür. Ebeveynlerin çalışma durumlarına bakıldığında hem 
bakım yükü $(p=0,355)$ hem de depresyon puanları $(p=1,00)$ arasında herhangi bir fark saptanmamıştır. Ailelerin gelir durumlarına bakıldığında ise hem bakım yükü. $(p=0,000)$ hem de depresyon $(p=0,00)$ puanları arasında istatistiksel olarak anlamlı derece fark bulunmuştur. $\mathrm{Bu}$ farkın gelir-giderine denk olan ailelerden kaynaklandığ1 görülmüş. Bu ebeveynlerin her iki puan grubundan da yüksek puan aldığı görülmüștür (Tablo 3).

Tablo 1. Engelli Çocuğa Sahip Ebeveynler ile Bakım Verilen Çocukların Sosyo-Demografik Özelliklerin Dağılımı

\begin{tabular}{|c|c|c|c|}
\hline \multicolumn{2}{|c|}{ Sosyo-Demografik Özellikler } & \multirow{2}{*}{$\begin{array}{l}\mathbf{n}(\mathbf{1 0 0 )}) \\
78\end{array}$} & \multirow{2}{*}{$\begin{array}{l}\% \\
78\end{array}$} \\
\hline Cinsiyet & Anne & & \\
\hline & Baba & 22 & 22 \\
\hline \multirow[t]{2}{*}{ Medeni durum } & Evli & 85 & 85 \\
\hline & Bekar & 15 & 15 \\
\hline \multirow[t]{2}{*}{ Yaş } & $26-39$ & 57 & 57 \\
\hline & 40 ve üzeri & 43 & 43 \\
\hline \multirow[t]{2}{*}{ Ĕ̈itim } & İlkokul & 64 & 64 \\
\hline & Lise & 36 & 36 \\
\hline \multirow[t]{2}{*}{ Çalışma Durumu } & Çalışıyor & 26 & 26 \\
\hline & Çalışmıyor & 74 & 74 \\
\hline \multirow[t]{2}{*}{ Bakım verilen Çocuk cinsiyet } & $\mathrm{K} 1 \mathrm{z}$ & 63 & 63 \\
\hline & Erkek & 37 & 37 \\
\hline \multirow[t]{3}{*}{ Bakım verilen Çocuk Yaş } & $0-6$ yaş & 35 & 35 \\
\hline & $7-12$ yaş & 31 & 31 \\
\hline & $13-18$ & 34 & 34 \\
\hline \multirow[t]{3}{*}{ Bakım verilen Çocuk Engel Durumu } & Fiziksel Engel & 17 & 17 \\
\hline & Zihinsel Engel & 59 & 59 \\
\hline & Genetik hastalık & 24 & 24 \\
\hline \multirow[t]{2}{*}{ Bakım verilen Çocuk Engel Şiddeti } & Hafif & 73 & 73 \\
\hline & Orta ve Şiddetli & 27 & 27 \\
\hline \multirow[t]{3}{*}{ Bakım verilen Çocuk Engel Zamanı } & Doğuştan & 69 & 69 \\
\hline & $0-1$ Yaş & 25 & 25 \\
\hline & 2-3 Yaş & 6 & 6 \\
\hline \multicolumn{2}{|c|}{$\begin{array}{ll} & \text { Toplam }\end{array}$} & 100 & 100 \\
\hline
\end{tabular}

Tablo 2. Engelli Çocuğa Sahip Ebeveynlerin Bakım Yükü ve Beck Depresyon Ölçeği Puanları

\begin{tabular}{|l|l|l|l|}
\hline \multicolumn{1}{|l|}{ Ölçeklerinin Puan Aralıkları } & n (100) & \% \\
\hline \multirow{5}{*}{ Bakım Yükü Ölçeği } & 21'in altı daha az yük ya da yük yok & 16 & 16 \\
\cline { 2 - 4 } & $21-40$ arası hafif yük & 48 & 48 \\
\cline { 2 - 4 } & $41-60$ arası orta ciddi yük & 22 & 22 \\
\cline { 2 - 4 } & $61-88$ arası ciddi yük & 14 & 14 \\
\hline \multirow{5}{*}{ Beck Depresyon Ölçeği } & 10 ve altı ise minimal düzey depresyon & 5 & 5 \\
\cline { 2 - 4 } & $10-18$ hafif düzey depresyon & 30 & 30 \\
\cline { 2 - 4 } & $29-19$ orta düzey depresyon & 17 & 48 \\
\cline { 2 - 4 } & $30-63$ ağır depresyon & 48 & 100 \\
\hline
\end{tabular}

Çalışmamızda bakım verilen çocuğun cinsiyeti ile bakım yükü $(p=0,3126)$ ve depresyon puanları $(p=0,884)$ arasında anlamlı bir fark saptanmamıştır. Çocuğun engel durumuna bakıldığında hem hafif hem de orta-şiddetli engelli çocuğa sahip ebeveynlerin bakım yükü $(\mathrm{p}=0,000)$ ve depresyon $(p=0,000)$ puanları arasında istatistiksel olarak anlamı derecede farklılık görülmüştür. Aynı zamanda çocuğun etkilenen ekstremitesi ile depresyon arasında da istatistiksel olarak anlamlı fark saptanmıştır $(\mathrm{p}=0,000)$. İki ve daha fazla ekstremitesinin etkilendiği çocuğa sahip olan ailelerin daha fazla depresyon puanına sahip olduğu görülmüştür. Bakım verilen çocukların 
yaşları ile ebeveynlerin bakım yükü ve depresyon durumları incelendiğinde hem bakım yükü $(\mathrm{p}=0,000)$ hem de depresyon $(\mathrm{p}=0,000)$ puanları arasında istatistiksel olarak anlamlı fark olduğu görülmüştür. $\mathrm{Bu}$ farkın bakım yükü puanında 13-18 yaş arası çocuğa sahip bakın veren ailelerin, depresyon puanında ise 7-12 yaş arası çocuğa sahip olan ailelerin oluşturduğu görülmüştür. Çocuğun engel zamanı ile ebeveynlerin bakım yükü $(\mathrm{p}=0,000)$ ve depresyon $(\mathrm{p}=0,000)$ puanları arasında istatistiksel olarak anlamlı fark görülmüştür. Çocukların engel zamanını doğuştan olarak tanımlayan ailelerin diğer ailelere oranla depresyon puanlarını yüksek olduğu, 0-1 yaş olarak tanımlayan ailelerin ise bakım yükü puanının yüksek olduğu görülmüştür.

Tablo 3. Bakım Veren Ebeveynlerin Özellikleri ile Bakım Yükü ve Depresyon Puanlarının Karşılaştırılması

\begin{tabular}{|c|c|c|c|c|c|}
\hline & & Bak & & Beck Depresy & \\
\hline & & n & $\begin{array}{r}\text { Toplam } \\
\text { X } \pm \text { SS }\end{array}$ & $\mathbf{n}$ & $\begin{array}{r}\text { Toplam } \\
\text { X } \pm \text { SS }\end{array}$ \\
\hline Ebeveynlerin & $26-40$ & 57 & $41,96 \pm 239$ & 57 & $45,91 \pm 261$ \\
\hline Yaşı & 40 Ve Üzeri & 43 & $61,83 \pm 265$ & 43 & $56,58 \pm 243$ \\
\hline & $\mathbf{u}^{*}$ & & 738,500 & & 964,000 \\
\hline & $\mathbf{p}$ & & ,001 & &, 063 \\
\hline Ebeveyn Cinsiyet & Anne & 78 & $47,58 \pm 371$ & 78 & $46,85 \pm 365$ \\
\hline & Baba & 22 & $60,84 \pm 133$ & 22 & $63,43 \pm 139$ \\
\hline & $\mathbf{u}^{*}$ & & 630,500 & & 573,500 \\
\hline & $\mathbf{p}$ & &, 055 & &, 016 \\
\hline Medeni Durum & Evli & 85 & $49,44 \pm 420$ & 85 & $49,50 \pm 420$ \\
\hline & Bekar & 15 & $56,53 \pm 848$ & 15 & $56,17 \pm 842$ \\
\hline & u* & & 547,000 & & 552,500 \\
\hline & $\mathbf{p}$ & &, 375 & & 0,402 \\
\hline Eğitim Durumu & İlkokul & 64 & $57,25 \pm 366$ & 64 & $67,59 \pm 432$ \\
\hline & Lise & 36 & $38,50 \pm 138$ & 36 & $20,11 \pm 724$ \\
\hline & $\mathbf{u}^{*}$ & & 720,000 & & 58,000 \\
\hline & $\mathbf{p}$ & &, 002 & &, 000 \\
\hline Ebeveynlerin & Çalışıyor & 26 & $46,04 \pm 119$ & 26 & $50,50 \pm 131$ \\
\hline Çalışma Durumu & Çalışmıyor & 74 & $52,07 \pm 385$ & 74 & $50,50 \pm 373$ \\
\hline & $\mathbf{u}^{*}$ & & 846,000 & & 962,000 \\
\hline & $\mathbf{p}$ & &, 355 & & 1,000 \\
\hline Gelir Durumu & Gelir Giderimden Düșük & 40 & 45,83 & 40 & 29,43 \\
\hline & Gelirim Giderime Denk & 49 & 62,16 & 49 & 69,60 \\
\hline & Gelirim Giderimden Fazla & 11 & 15,55 & 11 & 42,05 \\
\hline & $* * \mathbf{h}$ & & 25,664 & & 45,165 \\
\hline & $\mathbf{p}$ & &, 000 & &, 000 \\
\hline Bakım Verilen & Erkek & 37 & $54,24 \pm 200$ & 37 & $51,04 \pm 188$ \\
\hline Çocuğun & Kız & 63 & $48,30 \pm 304$ & 63 & $50,18 \pm 316$ \\
\hline Cinsiyeti & $\mathbf{u}^{*}$ & & 1027,000 & & 1145,500 \\
\hline & $\mathbf{p}$ & &, 316 & &, 884 \\
\hline Bakım Verilen & Hafif & 73 & $40,26 \pm 293$ & 73 & $44,14 \pm 322$ \\
\hline Çocuğun Engel & Orta ve Şiddetli & 27 & $78,19 \pm 211$ & 27 & $67,70 \pm 181$ \\
\hline Durumu & $\mathbf{u}^{*}$ & & 238,000 & & 521,000 \\
\hline & $\mathbf{p}$ & &, 000 & &, 000 \\
\hline Bakım Verilen & Tek Ektremite & 25 & $47,00 \pm 117$ & 25 & $70,64 \pm 176$ \\
\hline Çocuğun & İkiden Fazla Ekstremite & 75 & $51,67 \pm 387$ & 75 & $43,79 \pm 328$ \\
\hline Etkilenen & $\mathbf{u}^{*}$ & & 850,000 & & 434,000 \\
\hline Ekstremitesi & $\mathbf{p}$ & &, 480 & &, 000 \\
\hline Bakım Verilen & 0-6 Yaş & 53 & 29,70 & 53 & 33,98 \\
\hline Çocuğun Yaşı & 7-12 Yaş & 27 & 72,59 & 27 & 61,93 \\
\hline & 13-18 Yaş & 20 & 75,80 & 20 & 78,85 \\
\hline & $* * \mathbf{h}$ & & 59,834 & & 42,226 \\
\hline & $\mathbf{p}$ & &, 000 & &, 000 \\
\hline Bakım Verilen & Doğuştan & 69 & 52,30 & 69 & 43,89 \\
\hline Çocuğun Engel & 0-1 Yaş & 25 & 56,80 & 25 & 58,18 \\
\hline Zamanı & 2-3 Yaş & 6 & 3,50 & 6 & 94,50 \\
\hline & $* * \mathbf{h}$ & & 17,702 & & 19,964 \\
\hline & p & &, 000 & &, 000 \\
\hline Bakım Verilen & Fiziksel Engel & 17 & 58,35 & 17 & 82,62 \\
\hline Çocuğun Tanısı & Zihinsel Engel & 59 & 42,51 & 59 & 42,23 \\
\hline & $\begin{array}{l}\text { Genetik Hastalık Nedeni ile } \\
\text { Engel }\end{array}$ & 24 & 64,58 & 24 & 48,08 \\
\hline & $* * \mathbf{h}$ & & 11,714 & & 26,917 \\
\hline & $\mathbf{p}$ & &, 003 & &, 000 \\
\hline
\end{tabular}

*u= Mann Whitney U testi kullanılmıştır.

**h: Kruskal Wallis Testi kullanılmıştır. 
Bakım verilen çocukların tanıları ile bakım yükü $(\mathrm{p}=0,000)$ ve depresyon $(\mathrm{p}=0,000)$ puanları arasinda istatistiksel olarak anlamlı farklılık görülmüştür. Fiziksel engeli olan ve fiziksel anlamda bakıma ihtiyaç duyan çocukların ailelerinin diğer tanıları olan çocuklara oranla daha yüksek bakım yükü ve depresyon puanı aldığı görülmüştür (Tablo 3).
Engelli çocuğa bakım veren ebeveynlerin bakım yükü ve depresyon puanları arasında pozitif yönde ve orta düzey ilişki bulunmuştur. Korelasyon kat sayısı r: 0,439 olarak hesaplanmıştır. Bu değere göre bakım yükü arttıkça depresyon belirtilerinin de arttı̆̆ söylenebilir (Tablo 4).

Tablo 4. Ebeveynlerin Bakım Yükü ve Depresyon Puanları Arasındaki İlișki

\begin{tabular}{|l|l|l|}
\hline & Bakım Yükü Puanları \\
\hline & r* & p \\
\hline Beck Depresyon Puanları &, 439 & $\mathrm{P}<0.005$ \\
\hline
\end{tabular}

*Spearman Korelasyonu

\section{Tartışma}

Çalıșmamızda bakım veren ebeveynin anne-baba olma, evli bekar olma ve çalışma durumları ile bakım yükü puanları arasındaki fark bulunmamıştır. $\mathrm{Bu}$ sonuçlar yapılan çalışmalarla benzerlik göstermektedir [19-21]. Bakım veren ebeveynin yașı ile bakım yükü arasında anlamlı fark bulunmuştur. Özdemir ve arkadaşlarının, kanserli çocuğu olan ebeveynlerinin bakım verme yüklerini tespit etmek amacıyla yaptığı çalışmalarında annelerin yaşı arttıkça bakım verme yükününde arttığını saptamıştır [21]. Beyzatı'ıne ark.'larının hastanede tedavi gören çocukların annelerinde bakım yükünü belirlemek amacıyla yaptıkları çalışmalarında da benzer şekilde yaş ile bakım yükü puanları arasında anlamlı bir ilişki olduğu saptanmıştır [22]. Bu sonuç çalışmamızla benzerlik göstermektedir. Bakım verenlerin yaşı ilerledikçe engelli bireye bakmak ile ilgili sorumlulukların üstesinden gelmekte zorlanmaları bu sonuçta etkili olmuş olabilir.

Çalışmamızda gelir durumu ile hem bakım yükü hem de depresyon puanları arasında anlamlı fark bulunmuştur. Bakım veren ebeveynlerin, geliri giderinden düşük yada eşit olanlarında bakım yükü ve depresyon puanlarının arttığ́1 görülmüştür. Benzer şekilde birçok çalışmada çocuklarında kronik bir hastalığın olması, kanser olması ya da bakım gerektirecek bir hastalığın olması hem ailede maddi olarak yüksek bir gidere neden olmasından dolayı hem de bakım yükünün arttırdığı belirtilmektedir $[1,21,23]$. Aynı zamanda çalışmalarda, ailelerin özellikleri ile annelerin çocuklarına bakım vermek için işlerinden ayrılmasının ekonomik yetersizlik üzerinde etkili olduğu görülmüştür $[1,21,24,25]$.

Ebeveynlerin depresyon puanlarına bakıldığında, yaş, medeni durum ve çalışma durumu arasında bir fark saptanmamıştır. Çalışmamızda ebeveyn cinsiyetlerine bakıldığında ise istatistiksel olarak anlamlı fark saptanmıș ve babaların annelere oranla daha fazla depresif belirti gösterdiği görülmüştür. Karahan ve İslam'ın serebral parsili (SP) ve yaşlı hastalara bakım verenleri karşılaştırdıkları çalışmalarında, SP'li çocuklara bakım veren annelerin babalara oranla daha yüksek stres düzeyine sahip oldukları saptamıştır [26].
Çalışmamızın aksine başka çalışmalarda da annelerin babalara oranla daha fazla depresif belirti gösterdiği belirtilmektedir $[13,27,28]$. Bu sonuçta çalışmanın yapıldığı bölgenin etkili olabileceği düşünülmektedir. Maddi geliri düşük olan ailelerin fazla olması ve bu geliri tek başına babaların karşılıyor olması da bu durumun göstergesi olarak düşünülmektedir.

Ebeveynlerin eğitim durumu azaldıkça bakım yükü ve depresyon puanları arasında anlamlı fark olduğu tesbit edilmiştir. Alonson ve ark.'larının, karaciğer transplantasyonu nedeni ile kronik bakım verilen çocukların ebeveyleri ile yaptığı çalışmalarında, eğitim durumu azaldıkça bakım yükü puanlarında artış görüldüğünü saptamışlardır [29]. Posfay ve ark.'ları da çalışmalarında benzer şekilde eğitim durumu ile bakım yükü arasında anlamlı ilişki olduğunu saptamıştır [30]. Hastanede akut ya da kronik bir neden ile yatan çocukların anneleriyle yapılan bir başka çalışma, annelerin eğitim düzeyi arttıkça, aldıkları sosyal destek düzeyinin de arttığını, kayg1 ve depresyon düzeyinin azaldığını tespit etmiştir [25]. Buna rağmen literatürde bakım yükü puanları ve depresyon puanları ile ebeveynlerin eğitim durumu arasında anlamlı fark olmadığı belirten çalışmalar da yer almaktadır. Çalışmalarda bunun nedeninin ilkokul eğitim seviyesine ait olan ebeveynlerin sayısının fazla olmasından kaynaklandığı düşünülmüştür [13,19,21,23,31].

Çalışmamızda bakım verilen çocuğun cinsiyeti ile bakım yükü ve depresyon puanları arasında anlamlı bir fark olmadığı görülmüştür. Bu sonuç literatür ile benzerlik göstermektedir $[13,21,23]$. Toplumda cinsiyet rolleri anne-babalar tarafından belirlenmiş ve çocuklara da bu belirlenen roller üzerinden tanımlamalar yapılmıştır. Fakat toplum geliştikçe ve eğitim seviyesi arttıkça bu bakış açısı azalmaktadır [31]. Fakat bakım gereksinimlerinin arttığı engelli çocuklarda bakım verilen çocuğun cinsiyetinin bir öneminin olmadiğ 1 literatürle desteklenmiştir $[13,19,21,28]$. Ergin ve arkadaşlarını, engelli çocuğa sahip ebeveynlerin depresyon düzeyi ve etkileyen faktörlerin belirlenmesi amacıyla, 290 ebeveyni kapsayan çalıșmalarında, bakım verilen çocuk cinsiyeti ile depresyon puanları arasında 
anlamlı bir fark bulunmamıştır. Fakat kız çocuğuna sahip ebeveynlerin depresyon puanlarının daha yüksek olduğu belirtilmiştir [31].

Beyazıt ve ark.'nın, hastanede tedavi gören çocukların ebeveynlerinde bakım verme yükünü inceledikleri, 160 aileyi kapsayan çalışmalarında, kronik hastalığa sahip çocuğu olan ebeveynlerin bakım verme yükünün ve anksiyetelerinin yüksek olduğu görülmüştür [24]. Benzer şekilde çalışmamızda da engel durumu yüksek olan çocuklara bakım veren ebeveynlerin bakım yükü ile depresyon puanlarının ileri derecede anlamlı şekilde ilişkili olduğu görülmüştür [21,23,24,32]. İkeda ve ark.'ın bedensel engelli çocuklarda uyku problemi ve bakım yükünü inceledikleri, yüz ebeveyni kapsayan çalışmalarında çocukların engel durumu ile bakım yükü arasında anlamlı fark olduğu saptanmıştır [33]. Toki ve ark.'ın engelli çocuklara bakan ebeveynlerin bakım yükünü ölçmek amacı ile 134 ebeveyni içeren çalışmalarında, çocukların engel durumlarının artması ile bakım yükü puanları ve depresyon puanları arasında anlamlı ilişki saptamıştır ve engel durumu arttıkça hem bakım yükü puanları hem de depresyon puanlarının artış gösterdiği görülmüştür [34]. Çalışmamızda ailelerden, çocuklarının engel durumunu ekstremite etkilenmesi açısından değerlendirilmesi istenmiş ve iki ekstremiteden fazlasının etkilenmiş olduğu çocukların ailelerinde bakım yükü puanları arasında anlamlı bir fark bulunmazken, depresyon puanları arasında ileri derecede anlamlı bir fark görülmüştür. Bu durumun çocuğun etkilenen ekstremite sayısının ailelerin bakım yükünü etkilemediği fakat buna karşın çocuklarının ömür boyu engelli kalacak olmalarından kaynaklı kaygılarının depresyona neden olduğu sonucunu varılmıştır.

Bakım verilen çocuğunun engele sahip olma zamanı ya da kronik hastalığa sahip çocukların tanılanma zamanı ile bakım yükü ve depresyon puanlarının etkili olduğu görülmüştür. Çocukların tanılandıktan sonra yıllar geçtikçe aileye olan bakım yükünün artması, ailenin hastalık ve tanı sürecini kabullenmesi ya da tedaviye uyum sağlamasının bakım yükü ve depresyon puanlarındaki artışa neden olduğu çalışmalarla desteklenmiştir $[21,24,32]$. Çalışmamızda ise çocuğun tanı zamanı doğuştan olan ailelerin bakım yükü puanı yüksek iken, tanı zamanı 2-3 yaş olan ailelerin depresyon puanları ileri derecede istatistiksel olarak anlamlı bulunmuştur.

Çalışmamızda da çocukların engel tanısı ile bakım yükü ve depresyon puanları arasında anlamlı fark görülmüştür. $\mathrm{Bu}$ farkın fiziksel engele sahip çocuğu olan ebeveynlerden kaynaklı olduğu ve bu ebeveynlerin algıladıkları bakım yükü ve depresyon puanlarının yüksel olduğu görülmüştür. Bakım verilen çocuğun fiziksel engele sahip olması ve kişisel ihtiyaçlarını karşılayamaması aileye olan bakım yükünü arttırmaktadır. Aynı zamanda çocuğunun fiziksel olarak zorluk yaşadığını görmesi ebeveynlerde depresyona neden olmaktadır [27,32]. Toros'un zihinsel veya fiziksel engelli çocukların annelerdeki depresyon ve çocuklarını algılama şeklini saptamak amacıyla, 51 zihinsel/fiziksel engele sahip çocuk ve annesi ile 21 sağliklı çocuk ve annesiyle yaptığı çalışmasında, zihinsel veya fiziksel engelli çocukların annelerinin depresyon puanlarının daha yüksek oluğu görülmüştür [32]. Herken ve arkadaşları benzer şekilde çalışmalarında down sendromlu çocuğa sahip ebeveynlerin depresyon durumlarının yüksek olduğunu saptamışlardır [27].

\section{Sonuç}

Çalışmamızda, çocukların tanı alma zamanı, aldıkları tanı, bakım verilen yaş, etkilenen ekstremite, ebeveynlerin yaşı, çalışma durumu, eğitim durumu ve gelir durumu ile bakım yükü ve depresyon puanları ilişkili ve ileri düzeyde anlamlı bulunmuştur. Bu sonuçlar doğrultusunda;

Engelli çocuğu olan ailelere destek olacak politikalar geliştirilmeli.

Engelli bireye bakım veren ebeveynler yakından izlenmeli ve depresyon bulguları gözlenmelidir.

Engelli bireye bakım veren ebeveynlere sağlık profesyonelleri tarafindan bakım yükünü azaltmaya yönelik bakım ilkeleri ile hijyen eğitimleri verilmelidir.

Bakım yükünün artması ile ebeveynlerin kendilerine özel zaman ayıramayacağı göz önünde bulundurularak kendilerine kişisel zaman ayırabilme konusunda destek olunmalidir.

Bakımda sadece anne- baba değil abla, kardeş belki büyük anne ve baba gibi evin tüm bireylerini dahil ederek ebeveynlerin bakım yüklerinin azaltılmasına olanak sağlanmalı ve aile bir bütün olarak ele alınmalıdır.

Ebeveynlerin kamu kurum ve kuruluşlarındaki sosyal hizmet olanaklarından aktif bir şekilde yararlanmaları sağlanmalıdır.

Birinci, ikinci ve üçüncü basamak olmak üzere sağlığın her alanında aktif rol alan tüm sağlık profesyonellerinin engelli çocuğa sahip olan ebeveynleri sosyal destek alabilecek kurum ve kuruluşlara yönlendirmelerinin yararlı olabileceği düşünülmektedir.

\section{References}

1. Karadağ, G, Engelli Çocuğa Sahip Annelerin Yaşadıkları Güçlükler ile Aileden Algıladıkları Sosyal Destek ve Umutsuzluk Düzeyleri, TAF Preventive Medicine Bulletin, 2009.

2. Sevindik, F, Deveci, E, Demirok, A, Açık, Y, Engelli çocuğu olan kadınların demografik, psikosoyal ve engelli çocuğa ait doğumsal özelliklerinin incelenmesi, Sağlık ve Toplum Dergisi, 2006, 16, 3847.

3. Ulutaşdemir, N, Engelli Çocukların Eğitimi, Fırat Sağlık Hizmetleri Dergisi, 2007, 2.5, 119-130.

4. Yıldırım Sarı, H, Zihinsel engelli çocuğu olan ailelerde aile yüklenmesi [Family burden on families of children with intellectual disability caring], Cumhuriyet Üniversitesi Hemşirelik Yüksekokulu Dergisi., 2007.

5. World Health Organization, Who Global Disability Action Plan 2014-2021, Better Health For All People With Disability, World Health Organization, 2015. [Çevrimiçi]. Available at: https://apps.who.int/iris/bitstream/handle/10665/199544/978924150 9619_eng.pdf;jsessionid=84CD917CA62351031E1C9FD36B8490 $\mathrm{AB}$ ? sequence $=1$.

6. Sarı, S, Altıparmak, HY, Ebe ve Hemşirelerin Zihinsel Engelli Çocuklarla İlgili Bilgileri, TSK Koruyисu Hekimlik Bülteni, 2008, 7, 2, 127-132

7. Gitterman, Alex, ed. Handbook of social work practice with vulnerable and resilient populations. Columbia University Press, 2014

8. Mignor, D, Effectiveness of Use of Home Health Nurses to Decrease Burden \& Depression of Elderly Caregivers, Journal of psychosocial 
nursing and mental health services., 2000.

9. Allender, JA, Spradley, BW, Clients In Home Health, Hospice, and Long-Term Settings, Community Health Nursing Concepsts and Practice, 2001, 5, 739-753.

10. Lidell, E, Family support - a burden to patient and caregiver European Journal of Cardiovascular Nursing, 2002, 1, 149-152.

11. Özşenol, E, Işıkhan, F, Ünay, V, Aydın, B, Akın, Hİ, Gökçay, R, Engelli Çocuğa Sahip Ailelerin Aile İşlevlerinin Değerlendirilmesi, Gülhane Tip Dergisi, 2003, 45, 2, 156-164.

12. Damiani, VB, Responsibility and adjustment in siblings of children with disabilities: Update and review, Families in Society, 1999.

13. Girli, A, Yurdakul, A, Sarısoy, M, Özekes, M, Zihinsel Engelli ve Otistik Çocukların Ebeveynlerine Yönelik Grup Danışmanlığının Depresyon, Benlik Saygısı ve Tutumları Üzerine Etkisi, 10. Ulusal Psikoloji Kongresi'nde Sunulan Bildiri, Ankara Üniversitesi, Ankara, 1998.

14. İnci FH, Erdem, M, Bakım Verme Yükü Ölçeği’nin Türkçe'ye Uyarlanması Geçerlilik ve Güvenilirliği, Anadolu Hemşirelik ve Sağlık Bilimleri Dergisi, 2008.

15. Zarit, SH, Reever, KE, Bach-Peterson, J, Relatives of the impaired elderly: Correlates of feelings of burden, The gerontologist, 1980.

16. Ulusoy, M, Sahin, NH, Erkmen, H, Turkish version of the Beck Anxiety Inventory: Psychometric properties, Journal of Cognitive Psychotherapy, 1998.

17. Abdullah, C, Quantitative Data Analysis in Scientific Research Process with SPSS. Pegem Academy, 2018.

18. Beck, AT, Ward, CH, Mendelson, M, Mock, J, Erbaugh, J, An Inventory for Measuring Depression, Archives of general psychiatry, 1961.

19. Coşkun, D, Fiziksel Engelli Çocuğu Olan Ebeveynlerde Bakım Yükünün ve Aile Isşlevlerinin Değerlendirilmesi, Atatürk Üniversitesi, Sağlık Bilimleri Enstitüsü, (yayınlanmamış doktora tezi), Erzurum, 2013.

20. Hatipoğlu, ON, Obstrüktif uyku apne sendromlu hastaların eşlerinde yaşam kalitesi, anksiyete ve depresyonun değerlendirilmesi, Trakya Üniversitesi Tıp Fakültesi, (yayınlanmamış doktora tezi), 2011.

21. Özdemir, D, Şahin, FK, Küçük, ZA, Kanserli Çocuğu Olan Annelerin Bakım Verme Yüklerinin Belirlenmesi, Yeni Tıp Dergisi,2009, 26, 3, 153.

22. Beyazıt, U, Hastanede Tedavi Gören Çocukların Ebeveynlerinde Bakım Verme Yükünün İncelenmesi, Adnan Menderes Üniversitesi Sağlık Bilimleri Fakültesi Dergisi, 2017, 1, 1, 10-19.

23. Alahan et al, Kronik Hastalığı Olan Çocuğa Sahip Ebeveynlerin Bakım Verme Yükü, İn̈nü Üniversitesi Sağlık Bilimleri Dergisi, 2015, 4, 2, 1-5.

24. Beyazıt, U, Hastanede Tedavi Gören Cocukların Ebeveynlerinde Bakım Verme Yükünün İncelenmesi, Adnan Menderes Üniversitesi Să̆lık Bilimleri Fakültesi Dergisi,2017, 1, 1, 10-19.

25. Yüzer, B, Yiğit, S, Taşdelen, R, Çocuğu Hastanede Yatan Annelerin Aldığı Sosyal Destek İle Depresyon Düzeyleri Arasındaki İlişki, Atatürk Üniversitesi Hemşirelik Yüksekokulu Dergisi, 2006, 9, 4, 54 62

26. Yayan, EH, Düken, ME, Comparison of Caregiving Burden and Social Support Levels of Parents of Children Undergoing Liver Transplant, Journal of pediatric nursing, 2019.

27. Herken, SKH, Turan, M, Senol, S, Down sendromlu çocuğu olan anne babaların depresyon düzeyleri ve depresyonla başa çıkma becerileri, Çocuk ve Ergen Ruh Sağlığ Dergisi, 2000, 7, 3, 143-152.

28. Duman, H, Zihinsel engelli çocuğa sahip anne babaların kayg düzeylerinin karşılaştırılarak çocuğa yönelik beklentilerinin belirlenmesi, Dokuz Eylül Üniversitesi, İzmir, 1995.

29. Alonso, E M, Neighbors, K, Barton, F B, McDiarmid, SV, Dunn, S P, Mazariegos, GV, Bucuvalas, JC, Health-related quality of life and family function following pediatric liver transplantation, Liver Transplantation, 2008.

30. Posfay-Barbe, KM, Barbe, RP, Wetterwald, R, Belli, DC, McLin, VA, Parental functioning improves the developmental quotient of pediatric liver transplant recipients, Pediatric transplantation, 2013.

31. Ergin, M, Șen, D, Eryılmaz, N, Eryılmaz, N, Pekuslu, NE, Pekuslu, S, Kayac1, S, Engelli Çocuğa Sahip Ebeveynlerin Depresyon Düzeyi ve Etkileyen Faktörlerin Belirlenmesi, Atatürk Üniversitesi Hemşirelik Yüksekokulu Dergisi, 2007, 10, 1, 41-48.
32. Uğuz, O, Toros, S, İnanc, $F$, Colakkadıŏlu, BY, Zihinsel ve/veya Bedensel Engelli Çocukların Annelerinin Anksiyete, Depresyon ve Stres Düzeylerinin Belirlenmesi, Klinik Psikiyatri Dergisi, 2004, 7, $1,42-47$.

33. Ikeda, T, Nagai, T, Kato-Nishimura, K, Mohri, I, Taniike, M, Sleep problems in physically disabled children and burden on caregivers, Brain and Development, 2012

34. Toki, M, Washio, M, Furukawa, A, Narita, H, Yokogushi, K, Ishiai, S, Investigating Parental Caregiver Burden for Children with Disabilities using a Japanese version of the Zarit Caregiver Burden Interview (J-ZBI), The Japanese Journal of Rehabilitation Medicine, 2010

http://edergi.cbu.edu.tr/ojs/index.php/cbusbed isimli yazarın CBU-SBED başlıklı eseri bu Creative Commons Alıntı-Gayriticari4.0 Uluslararası Lisansı ile lisanslanmıştır.

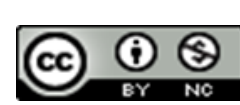

